\title{
THE ROLE AND IMPACT OF LOCAL ACTION GROUPS IN RURAL DEVELOPMENT OF KOSOVO
}

\author{
Nol Krasniqi ${ }^{\bowtie}$ \\ University of Prizren, Republika e Kosovës
}

\begin{abstract}
This research aims to present and analyze Local Action Groups and their role in Kosovo. Improving national wealth and reducing migration, especially from rural areas, is one of the biggest challenges. The LEADER program is considered to be a very successful rural development initiative of the European Union. Hence, this study examined the role of Local Action Groups as a main tool in implementing the LEADER approach. Focus was placed on how they work in Kosovo, their structure and organization, projects implemented, operation and characteristics of LAGs in Kosovo in the context of seven features of LEADER. The research concentrates on four municipalities where LAGs were examined, and the role of international organizations in training them. Descriptive statistics methods were used for the analysis. The study found that the LEADER approach in Kosovo is implemented more in theory and less in practice. Since they have been created, Local Action Groups in Kosovo have remained at an early stage of development. They need support from policymakers and international organizations.
\end{abstract}

Keywords: rural development, efficiency, local action group, LEADER approach

\section{INTRODUCTION}

Kosovo, as the youngest country in Europe, declared independence on February 17, 2008. Its target is clear and the pathway is towards European Union integration. Choosing this line means that Kosovo has to fulfill a number of criteria.
Kosovo is one of the poorest countries in Europe, and its economy reports one of the lowest GDP per capita. Poverty remains widespread in the country, with about $45 \%$ of the population living below the nationally defined poverty line (World Bank, 2010). The initial years of independence were focused more on strengthening the newly founded executive and legislative bodies. Besides other current duties, improving national wealth and reducing migration, especially from rural areas, is one of the biggest challenges.

The LEADER program is considered to be a very successful rural development initiative of the European Union. The program is based on a partnership of local governments, entrepreneurs and civil societies, and has introduced a completely new approach to rural development philosophy, methodology and practice in member states. Within the framework of the initiative, rural development projects have been implemented in more than 2000 European micro-regions in the last twenty years. Due to its effectiveness, LEADER has been integrated as a methodological axis into the rural development policy of the second pillar of the Common Agricultural Policy (Kassai, 2012).

Agriculture has historically been an important sector in Kosovo's economy. According to the World Bank, Kosovo is a country endowed with good quality agricultural land, and has been largely food self-sufficient in the past. The agricultural sector currently contributes about $12 \%$ to the country's GDP and accounts for approximately $35 \%$ of total employment in Kosovo (KAS,

\footnotetext{
$凶$ Nol Krasniqi, Faculty of Life and Environmental Sciences, University of Prizren, Republika e Kosovës, e-mail: nol.krasniqi@ uni-prizren.com, https://orcid.org/0000-0003-4570-3239
} 
Table 1. Financial support for LAGs in 2009-2012

\begin{tabular}{cccccccc}
\hline Year & $\begin{array}{c}\text { No. of } \\
\text { applications }\end{array}$ & $\begin{array}{c}\text { No. of projects } \\
\text { accepted }\end{array}$ & $\begin{array}{c}\text { \% of projects } \\
\text { accepted }\end{array}$ & $\begin{array}{c}\text { Budget } \\
\text { planned }\end{array}$ & $\begin{array}{c}\text { Aid intensity } \\
(\%)\end{array}$ & $\begin{array}{c}\text { Funds used } \\
\text { (EUR) }\end{array}$ & $\begin{array}{c}\text { Budget used } \\
(\%)\end{array}$ \\
\hline 2009 & 21 & 11 & $48 \%$ & 42,300 & $50 \%$ & 40,295 & $95.3 \%$ \\
2010 & 19 & 13 & $68 \%$ & 100,000 & $50 \%$ & 60,287 & $60.3 \%$ \\
2011 & 18 & 15 & $83 \%$ & 100,000 & $70 \%$ & 100,663 & $101 \%$ \\
2012 & 15 & 13 & $86 \%$ & 150,000 & $70 \%$ & 89,368 & $59 \%$ \\
\hline
\end{tabular}

Source: MTE Report 2012, Section 7.7.6 for 2009-2011; MAFRD, RDPD/Monitoring and Evaluation Unit for 2012.

2014b). However, the analysis of competitiveness of Kosovan agriculture indicates that only a small portion of farmers may actually compete in the regional, EU and international market. The main underlying causes of their low competitiveness are the small size of most agricultural businesses, land fragmentation, obsolete facilities and equipment, lack of funding for investments and limited know-how on modern production techniques. Additionally, most farms fail to meet the EU requirements for food safety and hygiene, animal welfare and environmental protection (MAFRD, 2014; KAS, 2014a).

Defining rurality in Kosovo is not the same as in EU countries. Since Kosovo, on the one hand, has a very high population density (166 persons per $\mathrm{km}^{2}$ ) and, on the other hand, the NUTS system has not yet been introduced, the OECD's methodology is currently not suitable for the definition of its rural areas (MAFRD, 2014). The definition of rural areas used by the Kosovo Agency for Statistics (KAS) in the 'Kosovo Population and Housing Census 2011' and other statistics is as follows: a non-urbanized geographical area-defined at settlement level - characterized by a lower population density and typically where much of the land is allocated to agriculture, compared to surrounding areas. In the 2014-2020 ARDP context, settlements with a population above 30,000, namely the cities of Pristina, Prizren, Gjilan, Peja, Mitrovica, Ferizaj and Gjakova, are classified as urban areas, while the rest of the Kosovan territory is considered as rural areas (MAFRD, 2014).

Implementing the LEADER program in Kosovo and strengthening Local Action Groups (LAGs) (created between 2007 and 2009) means that local partnership promotes rural development and helps increase decision-making in rural communities, follow a bottom-up approach and use other key features of LEADER. Showing the success stories of LEADER implementation in EU countries can be an efficient way to develop LAGs, and international donors can help achieve that goal.

As a policymaker, the Kosovan Ministry of Agriculture, Forestry and Rural Development tries to adopt policies relating to the CAP. In 2007-2013, on the initiative of the MAFRD, 30 Local Action Groups (LAGs) were established in Kosovo and covered the whole country. The LAGs in Kosovo are based on municipalities, and thus each municipality corresponds to one LAG. LAGs are registered as Non-Governmental Organizations according to Kosovan legislation. In the last few years, LAGs have implemented various projects for the benefit of their communities with financial support from the MAFRD, municipalities and other donor organizations (MAFRD, 2014).

Even though 30 LAGs have been established, not all of them are active. Only 21 Local Action Groups have applied for LEADER projects, and only 52 projects have been supported with EUR 290,613 until 2012. The allocated funds were disbursed in full only in 2011 when the support rate was increased to $70 \%$.

\section{LEADER PROGRAM IN KOSOVO AND ROLE OF LAGS}

\section{Objectives of the study}

The research study includes four objectives:

- to examine the role of Local Action Groups in rural development in Kosovo;

- to study the operation and characteristics of LAGs in Kosovo;

- to examine the role of international organizations as backbone donors for upgrading LAGs; 
Table 2. Analysis of research objectives

\begin{tabular}{|c|c|c|}
\hline Objectives & Data requirements & Method of data analysis \\
\hline $\begin{array}{l}\text { To examine the role of Local Action } \\
\text { Groups in rural development in Kosovo }\end{array}$ & $\begin{array}{l}\text { Primary and secondary data: general information about Local } \\
\text { Action Groups' structure, characteristics and activities }\end{array}$ & $\begin{array}{l}\text { Narratives and case study } \\
\text { analyses }\end{array}$ \\
\hline $\begin{array}{l}\text { To study the operation and characteris- } \\
\text { tics of LAGs in Kosovo }\end{array}$ & $\begin{array}{l}\text { Primary and secondary data: LEADER in the EU and re- } \\
\text { search results from the questionnaire }\end{array}$ & Narratives \\
\hline $\begin{array}{l}\text { To examine the role of international } \\
\text { organizations as backbone donors for } \\
\text { upgrading LAGs }\end{array}$ & Secondary data: general Information about donors & $\begin{array}{l}\text { Descriptive statistics such } \\
\text { as frequency tables }\end{array}$ \\
\hline $\begin{array}{l}\text { To examine the challenges and pros- } \\
\text { pects of LEADER in Kosovo }\end{array}$ & $\begin{array}{l}\text { Primary and secondary data: general information about Local } \\
\text { Action Groups' structure, characteristics and activities. } \\
\text { Past policy actions from } 2010 \text { to } 2013 \text { and } 2014 \text { to } 2020 \text {. } \\
\text { LEADER program in KOSOVO. }\end{array}$ & $\begin{array}{l}\text { Descriptive statistics such } \\
\text { as frequency tables }\end{array}$ \\
\hline
\end{tabular}

Source: own elaboration.

- to examine the challenges and prospects of LEADER in Kosovo.

Table 2 shows the analysis of research objectives which include: the objective of the study, data requirements and method of data analysis.

\section{METHODOLOGY}

Primary and secondary data was collected to achieve the objective of this study.

Eight questionnaires were e-mailed to Local Action Groups in order to collect data on their structure, work, projects, role in local communities etc. in different regions of Kosovo. It must be taken into consideration that the LEADER program is new in Kosovo which, contrary to developed European countries, lacks relevant experience, and that some of the LAGs established are passive. As regards participation in the survey, only four out of eight respondents showed the willingness to fill out the questionnaire.

The questionnaire was composed of two parts. The first one includes general information about Local Action Groups (name of the LAG, contact person name/ position/phone/e-mail, municipality covered and region). The second part includes more specific variables such as structure, characteristics and activities of LAG (date established; how the initiative was created; and the level of knowledge of the LEADER program, to check if they access funds from international organizations).

To find out how the LAG is structured and how the board is represented, the respondents were asked to list the stakeholders, other represented organizations and cooperators. To check if they are active during the year, they were asked about the number of meetings with board members and if they regularly attend meetings. As LAGs are part of municipalities, it is important to get to know the financial support from the municipality and the number of meetings with the mayor. The survey also provides data on their contacts with other active LAGs from the region, or on whether they implement common projects. The presidents of LAGs were asked to list the projects implemented (budget, main donors, main beneficiaries, and outcomes for each) the area of focus (in the case of finished projects) and the areas that will receive greater focus in the future: industry, agriculture, rural tourism, education, infrastructure, environment, minorities, gender, youth and other, if any.

Another question asked in the questionnaire is about the LAG's expectations vis-à-vis the 2014-2020 ARDP, their goals and plans which they want to achieve in the future.

\section{Secondary data}

An extended document analysis was carried out. Firstly, the study focused on the 2010-2013 Agricultural and Rural Development Plans and the 2014-2020 draft plan delivered by the Ministry of Agriculture, Forestry and Rural Development of Kosovo (MAFRD) which provides economic and social data for rural areas of Kosovo. Moreover, a report from international organizations was analyzed in order to check their role as backbone donors for upgrading and reactivating the LAGs. 
Table 3. Local Action Groups in Kosovan municipalities

\begin{tabular}{lcccccc}
\hline LAG & Municipality & Total population & $\begin{array}{c}\text { Area } \\
\mathrm{km}^{2}\end{array}$ & $\begin{array}{c}\text { Population } \\
\text { density }\end{array}$ & $\begin{array}{c}\text { No. of } \\
\text { settlements }\end{array}$ & Region \\
\hline LAG “AgroLipjani” & Lipjan & 57,605 & 338 & 170.4 & 62 & Pristina \\
LAG "Kalaja" & Novobërdë & 6,729 & 204 & 33.0 & 26 & Pristina \\
LAG "Vitia" & Viti & 46,987 & 270 & 174.0 & 39 & Gjilan \\
LAG "Gjeravica" & Deçan & 40,019 & 294 & 136.1 & 37 & Gjakovë \\
\hline
\end{tabular}

Source: elaborated based on KAS, 2011.

\section{METHOD OF DATA ANALYSIS}

The following analytical tools were used in analyzing the data to achieve the objectives of this study:

1) Descriptive statistics, such as frequencies, were calculated and the findings were shown in graphs and tables. This includes the role and function of Local Action Groups in different regions of Kosovo.

2) An analysis of various case studies was carried out to examine the role of international organizations as backbone donors for upgrading LAGs.

\section{General information about Local Action Groups' structure, characteristics and activities}

Table 3 shows the most important characteristics of LEADER Local Action Groups examined. It includes total population, the area of territory covered, population density, number of settlements involved and region names. Of all the LAGs covered by this study, LAG "Agrolipjani" (based in Lipjan) covers the largest area and population. It is located in the main region of Kosovo, Pristina, together with the LAG "Kalaja" which is based in a municipality of the Pristina region with the smallest total population and the lowest population density. The total population and population density figures in Table 7 were retrieved from the 2011 Census of the Kosovo Agency of Statistics (KAS).

\section{STRUCTURE OF LOCAL ACTION GROUPS}

Interviews were conducted with the presidents of the LAGs examined. Three of them had a bachelor degree in agriculture and one in public administration. Their qualifications probably made them engage more in projects related to agriculture. All of the LAGs were created in 2009. First, the LAG "Agrolipjani" was founded by the Ministry of Agriculture on January 25, 2009. Second, the LAG "Vitia" was established under the 20072013 Agricultural and Rural Development Program (ARDP) on March 11, 2009. Then, LAG "Gjeravica" was created in a partnership between the MAFRD and the EU on June 4, 2009. And finally, the LAG "Kalaja Novoberde" was set up in partnership with the MAFRD and the EU on August 24, 2009.

Fifty percent of board members were representatives of the public sector and the other $50 \%$ came from the private sector. Three LAGs have eight board members, four from the private sector and four from the public sector. The LAG "Vitia" has 10 board members. Stakeholders who compose the board include NGOs, farmer organizations, women organizations (in the LAG "Kalaja"), training centers, processing companies and youth organizations.

The author examined the level of LAG presidents' knowledge of the LEADER program. It was found that two of them had satisfactory knowledge while the other two respondents exhibited high levels.

According to the survey, LAGs organize regular board meetings. Two of the LAGs held meetings twice a month, or more frequently (as and if needed due to urgent issues). The LAG "Vitia" is the most active in terms of personal contacts. They organize meetings two-three times in a month, and sometimes every week. In other LAGs, meetings are held only five times a year. Usually, the meetings are attended by all board members.

LAGs are currently highly dependent on cooperation with their municipalities. In three cases, the municipality even co-finances LAG projects and also covers a part of other LAG expenses. One LAG has no relations with 
the municipality because of political and ethnicity problems. Since the Serb minority won the local elections and took executive power in the municipality of Novoberda, the new mayor prohibited them to work inside the municipality building and left them without office. However, the other three LAGs hold regular meetings with, and are supported by, the mayors. They work in the municipality building.

\section{PLANNING THE FUTURE OF LAGS}

The LAG "Vitia" plans to continue to be active in designing and implementing different projects, and to engage in further support for women and youth. To realize joint projects with great achievable success across the municipality of Viti, they intend to cooperate with neighboring LAGs. The LAG intends to continue their successful cooperation with the German Society for International Cooperation (GIZ), the representatives of LAGs and other local associations and the Departments of Economic Development in the municipalities of the region for to establish a regional marketing organization. This would benefit the local producers, producer associations and various other companies. On the other hand, the LAG "Kalaja" plans to focus on revising their strategy and designing new projects. The LAGs "Gjeravica" and "Agrolipjani" have relatively similar plans and continue working on new projects.
Figure 1 shows the fields which the LAGs plan to focus on in their future projects. The results suggest that all the respondents want to implement projects mainly in agriculture and rural tourism. These are the two key priorities. The reason for the popularity of these fields is the availability of and access to funds. It is obvious that agriculture gets support from the national government while rural tourism is largely supported by international organizations. Rural tourism can bring incomes and new job opportunities, and may prevent outmigration, especially of the youth.

Another important field which they want to focus on is the improvement of infrastructure. Improvements in rural service provision are also an important priority since the rural population often lack public services like healthcare, kindergartens, care for elderly/handicapped people, public transport, everyday services and other activities affecting the quality of their life.

Environmental protection was ranked the third most important factor for LAGs in this survey. According to MAFRD (2014) and KAS (2014c), water sewage is the biggest problem faced by rural areas since only $31 \%$ of rural households have access to public water sewage systems and $47 \%$ have either no or no proper water sewage system. The sanitation system of rural households is poor as sewage treatment does not exist and waste treatment is very patchy and without proper collection points. Wastewater from nearly $40 \%$ of rural households is released to channels, rivers etc. Another field which

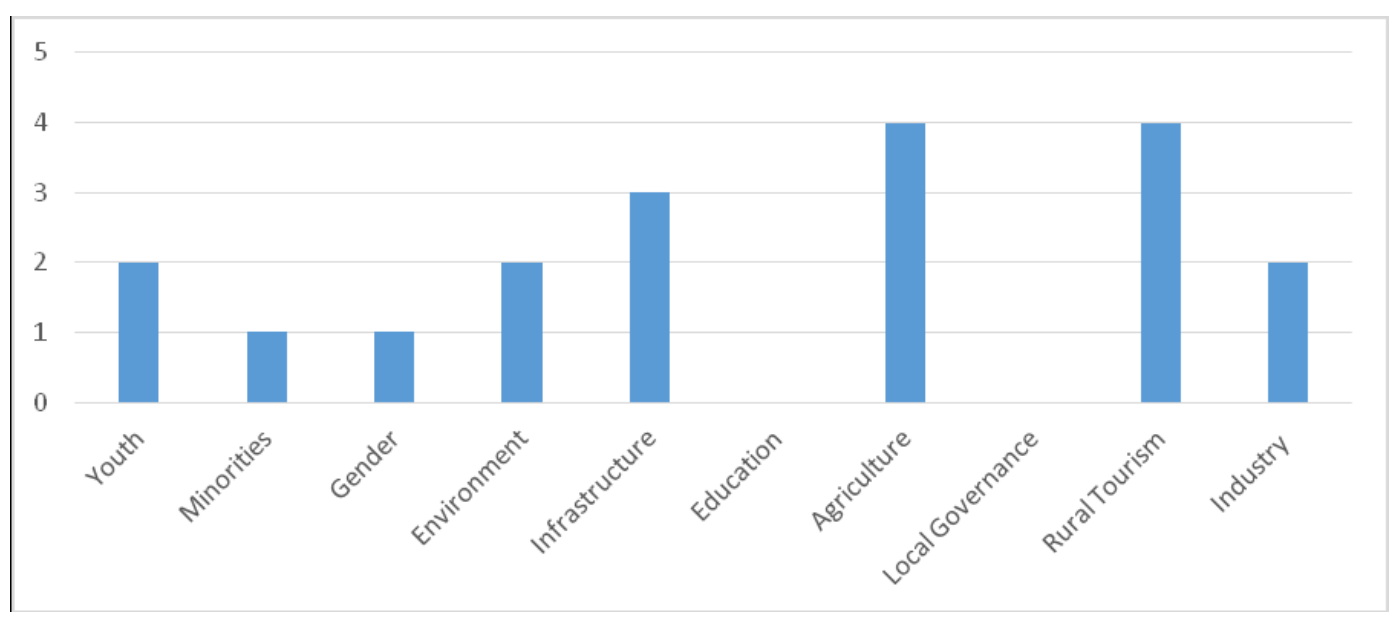

Fig. 1. Project areas on which the LAGs want to focus in the future Source: elaborated based on the questionnaire survey, 2016. 
Table 4. Projects implemented by the Local Action Group "Kalaja," Novoberde

\begin{tabular}{|c|c|c|c|c|}
\hline Project & Project topic & Period & Total budget & Beneficiaries \\
\hline $\begin{array}{l}\text { Collection of information } \\
\text { on how to use forests }\end{array}$ & Forest management & 2011 & EUR 1000 & LAG members \\
\hline $\begin{array}{l}\text { Cultural heritage catalogue } \\
\text { for the Gjilani region }\end{array}$ & $\begin{array}{c}\text { Preservation of cultural } \\
\text { heritage }\end{array}$ & 2013 & EUR 2500 & $\begin{array}{l}\text { Local communities of municipalities } \\
\text { in the Gjilani region }\end{array}$ \\
\hline $\begin{array}{l}\text { Tourist destination catalog } \\
\text { for the region of Gjilan }\end{array}$ & Tourism & 2013 & EUR 2500 & $\begin{array}{l}\text { Local communities of municipalities } \\
\text { in the Gjilani region }\end{array}$ \\
\hline $\begin{array}{l}\text { Plan to establish a new } \\
\text { slaughterhouse "Luli } \\
\text { Gjilan" }\end{array}$ & Agriculture & 2011 & $\begin{array}{l}\text { EUR 280,000 } \\
\text { Co-implementer }\end{array}$ & People of Kosovo \\
\hline $\begin{array}{l}\text { Organizing trainings for } \\
\text { raspberry producers }\end{array}$ & Training & 2014 & EUR 470 & Farmers, raspberry producers \\
\hline Seed-starting supplies & Agriculture & 2010 & EUR 5900 & $\begin{array}{l}\text { Farmers from the Novoberda } \\
\text { municipality }\end{array}$ \\
\hline $\begin{array}{l}\text { Project for the preservation } \\
\text { of cultural facilities }\end{array}$ & $\begin{array}{c}\text { Preservation of cultural } \\
\text { heritage }\end{array}$ & 2009 & EUR 2500 & $\begin{array}{c}\text { Community of the Novoberda } \\
\text { municipality }\end{array}$ \\
\hline
\end{tabular}

Source: elaborated based on the questionnaire survey, 2016.

is important, though not a priority, is the industry (with a focus on youth, too). Although gender and minorities are mentioned by the LAG "Vitia," there are no clear plans in this regard.

\section{IMPLEMENTED LAG PROJECTS (BUDGET, MAIN DONORS, MAIN BENEFICIARIES)}

The table above presents the projects implemented by the LAG "Kalaja" since it has been established. From 2009 to 2014, they implemented and assisted in seven projects with a total budget of EUR 294,870. The LAG "Kalaja" was a co-implementer supporting a private investor in establishing a meat processing factory. The LAG contributed by supplying relevant information (e.g. the numbers of cattle in the municipality).

Novoberde is well known for its cultural heritage and the famous old castle (the name of the LAG, "Kalaja," means castle). Therefore, projects were mainly targeted at preserving and repairing cultural facilities, and received dedicated funding.

The table above presents the projects implemented by the LAG “Gjeravica." In 2009, the LAG did not handle any project but seven projects have been implemented since then with a total budget of EUR 87,448.20.
The projects were focused on different aspects of rural living, including infrastructure improvements and facilities for young people (namely, a sport field and a playground for children). Some environmental projects were also supported, for instance one for water purification and another one for structuring the river bed. Also, three cemetery fences were built and economic activities were diversified for the local community. Besides, a local development strategy was drafted to the benefit of entrepreneurs and NGOs.

Table 6 presents the projects of the LAG "Agrolipjani" which started implementing projects one year after its establishment in 2010. They completed a total of seven projects financed with a budget of EUR 77,453, Primarily including infrastructural projects. Building fences for two primary schools resulted in establishing new green areas and improving the school yard. A fence was also built to entertain the youth and enhance sports facilities. Other two projects consisted in building a new road and a new bridge which made it easier for farmers to access agricultural land and prevent traffic and flooding risks. They also focused on their internal efficiency by updating the project framework and improving performance with a new office, inventory and manager. 
Table 5. Projects implemented by the Local Action Group "Gjeravica"

\begin{tabular}{|c|c|c|c|c|}
\hline Project & Project topic & Period & Total budget and the resources & Beneficiaries \\
\hline $\begin{array}{l}\text { Building a sports field in the Irzniq } \\
\text { village }\end{array}$ & $\begin{array}{c}\text { Settlement } \\
\text { development }\end{array}$ & 2010 & $\begin{array}{c}\text { EUR 10,095.00 } \\
\text { MAFRD and municipality of Deçan }\end{array}$ & $\begin{array}{l}\text { Young population of } \\
6 \text { settlements }\end{array}$ \\
\hline $\begin{array}{l}\text { Diversification of economic activi- } \\
\text { ties in the western region }\end{array}$ & $\begin{array}{c}\text { Settlement } \\
\text { development }\end{array}$ & 2012 & $\begin{array}{l}\text { EUR } 15,000.00^{*} \\
\text { European Commission and munici- } \\
\text { pality of Deçan }\end{array}$ & $\begin{array}{l}\text { Community of the Deçan } \\
\text { municipality }\end{array}$ \\
\hline $\begin{array}{l}\text { Water purification and bed improve- } \\
\text { ment in the Preljep river }\end{array}$ & Environment & 2012 & $\begin{array}{c}\text { EUR 10,000.00 } \\
\text { MAFRD and municipality of Deçan }\end{array}$ & $\begin{array}{c}\text { Community of the Pejlep } \\
\text { village }\end{array}$ \\
\hline Cemetery fencing in Carrabreg & Infrastructure & 2012 & $\begin{array}{c}\text { EUR } 13,150.20 \\
\text { MAFRD and municipality of Deçan }\end{array}$ & $\begin{array}{l}\text { Community of settlements } \\
\text { in Carrabreg }\end{array}$ \\
\hline Playground for children & Youth & 2013 & $\begin{array}{c}\text { EUR } 8,150.00 \\
\text { German embassy and municipality } \\
\text { of Deçan }\end{array}$ & $\begin{array}{l}\text { Children from different } \\
\text { settlements }\end{array}$ \\
\hline $\begin{array}{l}\text { Cemetery fencing in Gllogjan and } \\
\text { Irzniq }\end{array}$ & Infrastructure & 2013 & $\begin{array}{c}\text { EUR 24,989.00 } \\
\text { MAFRD and Deçan MP }\end{array}$ & $\begin{array}{l}\text { Community of settlements } \\
\text { in Gllogjan and Irzniq }\end{array}$ \\
\hline $\begin{array}{l}\text { Drafting the Local Development } \\
\text { Strategy }\end{array}$ & Other & 2014-16 & $\begin{array}{c}\text { EUR } 6.000,00 \\
\text { MAFRD and municipality of Deçan }\end{array}$ & $\begin{array}{c}\text { Community, entrepreneurs } \\
\text { and NGOs }\end{array}$ \\
\hline
\end{tabular}

${ }^{*}$ The project was implemented in 5 western municipalities of Kosovo. The amount allocated to the Decani municipality was EUR $15,000$. Source: elaborated based on the questionnaire survey, 2016.

Table 6. Projects implemented by the Local Action Group “Agrolipjani”

\begin{tabular}{|c|c|c|c|c|c|}
\hline Project & Project topic & Period & $\begin{array}{l}\text { Total budget and } \\
\text { the resources }\end{array}$ & Beneficiaries & Results \\
\hline $\begin{array}{l}\text { Building a fence for the } \\
\text { sports field in the Babush } \\
\text { settlement }\end{array}$ & Youth & 2010 & EUR $10,000.00$ & Community & $\begin{array}{l}\text { Developing sport activities } \\
\text { Youth entertainment }\end{array}$ \\
\hline $\begin{array}{l}\text { Building a fence for the } \\
\text { primary school in the Rufc } \\
\text { settlement }\end{array}$ & Infrastructure & 2011 & EUR $10,000.00$ & $\begin{array}{l}\text { Pupils from the } \\
\text { Migjeni primary } \\
\text { school }\end{array}$ & $\begin{array}{l}\text { New green areas and improved } \\
\text { school yard. } \\
\text { Protecting the pupils against } \\
\text { traffic risks. }\end{array}$ \\
\hline $\begin{array}{l}\text { Building a new bridge in the } \\
\text { Baice settlement }\end{array}$ & Infrastructure & 2012 & EUR 10,000.00 & Community & $\begin{array}{l}\text { Improvements in rural living } \\
\text { Prevention of traffic } \\
\text { and flooding risks }\end{array}$ \\
\hline $\begin{array}{l}\text { Building a fence for the pri- } \\
\text { mary school in the Gadime } \\
\text { settlement }\end{array}$ & Infrastructure & 2012 & EUR $10,000.00$ & $\begin{array}{l}\text { Pupils from the Ze- } \\
\text { nel Hajdini primary } \\
\text { school }\end{array}$ & $\begin{array}{l}\text { New green areas and improved } \\
\text { school yard. } \\
\text { Protecting the pupils against } \\
\text { traffic risks. }\end{array}$ \\
\hline $\begin{array}{l}\text { Building a new road in } \\
\text { Gllavicë }\end{array}$ & Infrastructure & 2013 & EUR 23,943.50 & Rural community & $\begin{array}{l}\text { Improvements in rural living } \\
\text { Easy access for farmers to } \\
\text { agricultural land }\end{array}$ \\
\hline $\begin{array}{l}\text { Review of the Local Devel- } \\
\text { opment Strategy }\end{array}$ & $\begin{array}{c}\text { Settlement } \\
\text { development }\end{array}$ & 2014 & EUR $6,540.00$ & LAG “AgroLipjani” & Updating the project framework \\
\hline $\begin{array}{l}\text { Improving the performance } \\
\text { of the LAG "Agrolipjani" }\end{array}$ & Other & 2015 & EUR 6,960.00 & LAG “AgroLipjani” & $\begin{array}{l}\text { Functionality of LAG office } \\
\text { with inventory and manager }\end{array}$ \\
\hline
\end{tabular}

Source: own compilation based on a questionnaire survey, 2016. 
According to research findings, no rural tourism projects have been implemented since the establishment of this LAG. Infrastructure was a priority axis for the projects.

Table 7 presents the projects of the LAG "Vitia" implemented with a total budget of EUR 76,960.00. The LAG started to operate in 2009 when already two projects were implemented in the field of agriculture and rural tourism. Greenhouses for crop and vegetable producers were built with resources of the MAFRD and the municipality of Vitia. A total of 34 farmers benefited from this project.
In 2009, the LAG started to focus on rural tourism by organizing fair initiatives, including the development of PR materials such as promotional notebooks. The aim of this project was to promote domestic products and traditional food, as reflected in the slogan "Protecting our traditional values." In the first year, the LAG found itself in a precarious situation because of the shortage of funds. However, since then, it has been supported by the municipality and the IKC organization with an annual amount of EUR 1,500.

Two infrastructural projects were implemented: a fence was built in a sports field; and a new football

Table 7. Projects implemented by the LAG "Vitia"

\begin{tabular}{|c|c|c|c|c|}
\hline Project & Project topic & Period & $\begin{array}{l}\text { Total budget } \\
\text { and the resources }\end{array}$ & Beneficiaries \\
\hline Greenhouse frame & Agriculture & 2009 & $\begin{array}{c}\text { EUR } 8,000 \\
50 \%-50 \% \\
\text { MAFRD and municipality }\end{array}$ & 34 farmers \\
\hline $\begin{array}{l}\text { Promoting domestic products and tradi- } \\
\text { tional food with the slogan "Protecting } \\
\text { our traditional values" }\end{array}$ & Tourism & 2009 & $\begin{array}{l}\text { Not funded project, } \\
\text { voluntary work }\end{array}$ & Local producers \\
\hline Building a fence & Infrastructure & 2010 & $\begin{array}{c}\text { EUR } 10,000 \\
50 \%-50 \% \\
\text { MAFRD and municipality }\end{array}$ & $\begin{array}{l}\text { Community of the Vitia } \\
\text { municipality }\end{array}$ \\
\hline $\begin{array}{l}\text { Promoting domestic products and tradi- } \\
\text { tional food with the slogan "Protecting } \\
\text { our traditional values" }\end{array}$ & Tourism & $\begin{array}{l}2012 \\
2013 \\
2014 \\
2015\end{array}$ & $\begin{array}{l}\text { EUR 1500/ EUR 1500/ } \\
\text { EUR 1500/ EUR 1500 Munici- } \\
\text { pality, LAG "Vitia" and IKC }\end{array}$ & Local producers \\
\hline Operation of LAGs & Training & $2012-2013$ & GIZ, a German organization & $\begin{array}{l}\text { Community of the Vitia } \\
\text { municipality }\end{array}$ \\
\hline Equipment and financial support & Agriculture & 2013 & $\begin{array}{l}\text { LAG "Vitia," LAG "Rural+" } \\
\text { and the marketing office of the } \\
\text { Gjilan municipality EU funds } \\
\text { accessed: EUR } 16.000\end{array}$ & $\begin{array}{l}\text { Two women's organiza- } \\
\text { tions and six farmers }\end{array}$ \\
\hline $\begin{array}{l}\text { Sports fields; football and volleyball } \\
\text { field in the primary school of the Smire } \\
\text { settlement }\end{array}$ & $\begin{array}{l}\text { Settlement } \\
\text { development }\end{array}$ & $2013-2014$ & $\begin{array}{l}\text { MAFRD } \\
\text { EUR 25,000 }\end{array}$ & $\begin{array}{l}\text { Pupils and the entire } \\
\text { community surrounding } \\
\text { the settlement }\end{array}$ \\
\hline LAGs planning & $\begin{array}{l}\text { Other and } \\
\text { training }\end{array}$ & 20142015 & $\begin{array}{l}\text { EUR } 5000 \\
\text { MAFRD }\end{array}$ & $\begin{array}{l}\text { Entire community of } \\
\text { the Vitia municipality }\end{array}$ \\
\hline $\begin{array}{l}\text { Performance of selected LAGs in } 2015 \text {; } \\
\text { new manager and new office for the LAG } \\
\text { "Vitia" }\end{array}$ & Other & $2015-2016$ & $\begin{array}{l}\text { EUR } 6960 \\
\text { MAFRD }\end{array}$ & $\begin{array}{l}\text { Entire community of } \\
\text { the Vitia municipality }\end{array}$ \\
\hline $\begin{array}{l}\text { Playground in the yard of the primary } \\
\text { school in the Sllatine settlement }\end{array}$ & $\begin{array}{c}\text { Settlement } \\
\text { development }\end{array}$ & 2016 & $\begin{array}{l}\text { Ongoing project of the German } \\
\text { embassy }\end{array}$ & Children \\
\hline
\end{tabular}

Source: elaborated based on the questionnaire survey, 2016. 
and volleyball field was built in a village (the pupils and the entire community surrounding the settlement were directly targeted).

Another project funded by the EU provided equipment and financial support to two women's organizations and six farmers. Additionally, this LAG focused on structural improvements; they managed to access funds from international organizations (such as the German GIZ) for purchasing office equipment, building experience and training. They also reviewed their local development strategy using funds from the MAFRD.

In addition, the president of the LAG stressed that in early 2016, they initiated a new project to build a playground for children. Based on the number and type of projects implemented, it can be concluded that they were more organized and more active than the other three LAGs covered by this study.

\section{COMPARISON OF 4 KOSOVAN LOCAL ACTION GROUPS BASED ON THE 7 PRINCIPLES OF THE LEADER APPROACH}

\section{Key features of the LEADER approach:}

Feature 1. Area-based local development strategies In this case, the LAG "Kalaja" covers an area with a population of only 6,729. Note that these people do not share the same tradition because they are of different ethnicities (Albanian and Serbian). As regards population, the three other LAGs covered by this study are consistent with the guideline of Feature 1. The LAG elaborates a Local Development Strategy (LDS) which considers the covered area's strengths, weaknesses, opportunities and threats and focuses on its local potential.

It was found that the examined LAGs cover only one municipality and that cooperation (including intermunicipal cooperation) is relatively poor. Based on their LDS, they implement projects by themselves instead of helping others to do it (EC, 2006).

Feature 2. Bottom-up approach Based on the feature 2, in some cases the bottom-up approach do not include all the local actors in partnership. Shortal (2008) states that some groups (such as Protestants, women and farmer families) do not participate in different types of official partnerships (including LEADER partnerships). However, she does not identify these groups as socially excluded since it could lead to a situation in which the activities that they are involved in are overlooked. She claims that "non-participation can represent a valid and legitimate choice, and often one made from a position of power" $(2008$, p. 3). Despite this, in some Kosovan regions inhabited by minorities like Serbs, these ethnicities do not want to be socially included at all because their political representatives do not recognize Kosovo as a country and work closely with Serbian institutions. They do not accept local and central authorities of Kosovo, and this is mainly the case in northern regions bordering Serbia where Belgrade's influence is stronger. The worst case is that of the municipality of Novoberda; the new mayor, a person of Serbian ethnicity, did not allow the LAG "Kalaja" to use the municipality building because the group consists of people of Albanian ethnicity.

However, the author believes that the four LAGs examined can be considered to be based on a top-down approach rather than on a bottom-up approach. Note also that the partnership work was controlled by the municipality in cooperation with the ministry.

Feature 3. Local public-private partnerships: Local Action Groups

According to this principle, LAGs establish local public-private partnerships. They aggregate and combine available human and financial resources from the public sector, private sector, and the civic and voluntary sector (EC, 2006). Although these partnerships are all present in the four LAGs examined, members from the private sector are less active than their peers from the public sector (and are not paid).

Feature 4. Integrated and multi-sectoral actions Results from surveyed LAGs found out that LAGs are not linked with the aim of this Feature. They are concentrated only in projects in infrastructure. This is because the Ministry of Agriculture (MAFRD) only finances LAG projects in certain fields, e.g. small-scale infrastructure projects like construction of school fences, graveyards etc. These infrastructural projects address the basic needs of local communities but do not drive economic development in the region.

\section{Feature 5. Innovation}

This feature is important as there is a relatively low density of human resources and connection to rural areas. 
Innovative solutions must be found regarding new products, processes and markets in order to prevent a back$\log$ of these areas in comparison to urban zones. It is necessary to provide innovative LAGs with operational freedom and flexibility in decision-making (EC, 2006).

However, the four LAGs examined have not implemented any kind of innovative activities, and have not entered into cooperation with research centers or universities. They focused more on MAFRD funds which are allocated to specific fields such as infrastructure, school fences, rivers and street restoration.

\section{Feature 6. Networking}

Exchanging experiences and achievements is a major task of LAGs in disseminating their success. Regional, national and international networks bring different LAGs together and arrange opportunities for information exchange (EC, 2006).

Although all LAGs in Kosovo have taken part in RDN, the respondents believe that it does not play a significant role in their activities. The four LAGs had only a few experiences to share.

\section{Feature 7. Cooperation}

According to research findings, one of the LAGs did not enter into any kind of cooperation with other LAGs. The other three LAGs had contacts with their peers but with those based in their regions. They met within the Rural Development Network (RDN) and had some common projects, but the idea to cooperate came from international organizations who offered the possibility to apply for funds. In order to file an application, the LAGs were required to form a group of more than two partners. The author believes that they should focus more on approaching with new ideas and to cooperate with other active LAGs.

\section{CONCLUSION AND RECOMMENDATIONS}

Research results showed that the LEADER approach in Kosovo is understood theoretically, but is not properly put in practice. Since they have been created, Local Action Groups in Kosovo have remained at an early stage of development. Of the 30 LAGs established, almost half are still inactive. The LAGs who participated in this survey were created in 2009 through a partnership between the MAFRD and the EU. Rural development and agriculture play a very important role in providing employment opportunities and generating incomes in Kosovo. Unemployment is still one of the biggest issues affecting Kosovan rural areas which also face basic infrastructural and economic problems. Economic diversification is still at an early stage; people continue to be largely engaged in agricultural activities.

Although the LAGs' operations and projects deviate much from the principles of the LEADER approach, it is not their fault. The main competent authorities should reduce the structural and organizational gap between Kosovan and European LAGs.

This study found that LAGs are currently highly dependent on cooperation with their municipalities. In three cases, the municipality even co-finances LAG projects and also covers a part of other LAG expenses. LAGs do not have independent workplaces or offices; all of them work in municipality buildings.

When implementing their projects, they almost always rely on funds from the MAFRD and municipalities. In only few cases, they accessed project funds from the European Commission and international organizations. In addition, some of them are supported by international organizations which are more focused on capacity building and updating the LAGs' strategy.

They face diverse challenges; so far, LAGs have been in a very difficult position and have experienced financial problems preventing them from functioning normally. Nevertheless, they were supported by the MAFRD. They had to borrow money from different sources to implement their projects, and they received a refund only upon completing the implementation process.

The LAGs have a lot of expectations vis-à-vis the 2014-2020 Agricultural and Rural Development program. They mentioned that it would be helpful for them to access trainings on how to apply for EU funds in the future. The infrastructure of LAGs should be also improved in the current programming period. For instance, they need offices where they could work normally. In addition, bureaucracy should be reduced in the application system for projects funds. They also want to play a more significant role inside the municipality to develop the local rural economy.

The seven key features (area-based local development strategies; bottom-up approach; integrated and multi-sectoral actions; local public-private partnerships; innovation; networking; and cooperation) should be followed in order for LEADER to be successfully 
implemented. The research findings regarding the operation of LAGs in Kosovo show that none of them fully complies with the seven key features of LEADER approach.

Specific objectives laid down under Measure 303 (preparation and implementation of LDS LEADER approach ARDP 2014-2020) stipulate that Local Action Groups should follow the seven key features of LEADER. In this case, the LAGs will have a totally new structural organization. There will no longer be one LAG per municipality as it has been until now. Instead, they will work at regional and inter-municipal level, and they will need to update their local development strategies. Diverse intensive strategy trainings are recommended for LAGs which should be financed by the ministry or international donors.

The fundamental needs of LAGs should be addressed in order for them to survive. They need support in finding office space, equipment and cars for field trips. Support for LAGs should be ensured by municipalities in cooperation and agreement with competent ministries, such as the MAFRD and the Ministry of Local Government Administration.

Competent policymakers, including at the bottom level of government (municipalities), should stimulate inactive LAGs by attracting them and promoting the LEADER approach in regions where no projects have been implemented by LAGs. Local communities should be encouraged to take responsibilities for their own regions by showing them the benefits of the LEADER approach.

LAGs should focus on taking bottom-up initiatives; they should cooperate more with regional and international organizations. Organizing study trips would be a good recommendation for them to see good practices in projects implemented. Joint conferences, workshops and experience sharing would strengthen cooperation and partnership. Moreover, LAGs should not view each other as competitors.

Another important recommendation for LAGs is to improve their PR activity. They should focus on less expensive measures, such as social media (Facebook, Twitter etc.). Nowadays, Internet is being used and provided in rural areas, too. Local communities can learn more about LEADER and LAGs, and can share good examples, projects implemented and plans for the future. Raising awareness of their work can attract the local community for a better partnership.
Research results also show that LAGs are eager to apply for EU funds. Hence, the competent authorities should organize trainings for LAGs on how to apply for funds. As a consequence, instead of focusing only on ministry funds, the LAGs could expand the scope of their projects and become independent.

Last but not least, this study recommends to depoliticize LAGs from municipalities or any kind of activities related to politics. LAGs should not be seen or used as political tools. This is a particularly sensitive issue in some regions where different ethnicities live. It can cause problems, lead to mistrust from local communities, and could undermine the fundamental principles of the LEADER approach.

\section{REFERENCES}

EC (European Commission). (2006): The Leader Approach: a basic guide. Luxembourg. Retrieved Feb $7^{\text {th }} 2016$ from: http://ec.europa.eu/agriculture/publi/fact/leader/2006 en.pdf

EUO (2015). European Commission Instrument for Pre-accession Assistance (IPA II) 2014-2020 - Further Support to Kosovo's Development of the Agri-Rural Sector and Food Safety [Report]. European Union Office in Kosovo.

GIZ (2014). Local Action Groups in Kosovo. Study on status quo and capacity development needs. GIZ.

KAS (Kosovo Agency of Statistics). (2011). Kosovo Population and Housing Census 2011 -Final Report. Retrieved Sep $19^{\text {th }} 2016$ from: http://unstats.un.org/unsd/censuskb20/KnowledgebaseArticle10700.aspx

KAS (Kosovo Agency of Statistics). (2014a). Agriculture Census 2014. Retrieved Sep $18^{\text {th }} 2016$ from: https://ask. rks-gov.net/ENG/agriculture

KAS (Kosovo Agency of Statistics). (2014b). Economic Accounts for Agriculture 2014. Retrieved Sep 13 ${ }^{\text {th }}$ 2016 from: https://ask.rks-gov.net/en/agr/category/103eaa?download $=35$ : economic-accounts-for-agriculture-2014

KAS (Kosovo Agency of Statistics). (2014c). Results of Household Budget Survey 2014. Retrieved Aug 9 2016 from: https://ask.rks-gov.net/en/hbs/category/115-resultsof-household-budget-survey?download=1455:results-ofhousehold-budget-survey-2014

Kassai, Z., Farkas, T. (2012). Participation in Local Rural Development Partnerships. Ann. Pol. Ass. Agric. Agribus. Econ., 14(6), 104-108.

Kassai, Z., Goda, P. (2011). Evaluation of Local Rural Development Strategies in Hungary. Ann. Pol. Ass. Agric. Agribus. Econ., 13(6), 83-88. 